\title{
The examination of work-related musculoskeletal discomforts and risk factors in veterinarians
}

\author{
Mesut Ergan, Ferdi Başkurt, and Zeliha Başkurt \\ Department of Physiotherapy and Rehabilitation, Faculty of Health Sciences, Süleyman Demirel University, Isparta, \\ Turkey
}

[Received in June 2017; Similarity Check in June 2017; Accepted in August 2017]

\begin{abstract}
This study aimed to determine the frequency of work-related musculoskeletal discomforts (WMSDs) observed in veterinarians and the risk factors that may bring about these. Two hundred and seven veterinarians working in three provinces in south west Turkey were included in the study. The demographic and occupational information on the participants was recorded. The Modified Nordic Musculoskeletal Questionnaire was used to evaluate the musculoskeletal problems of different body parts, which cause difficulties at work and result in staying away from work. $49.8 \%$ of veterinarians mostly have problems with lower back, $41.1 \%$ with back, and $39.1 \%$ with neck. The frequency of WMSDs tends to increase with the progress of professional experience. Three work-related activities during which veterinarians experience most difficulties while at work are obstetric procedures $(28 \%)$, vaccination $(25.6 \%)$, and driving $(23.2 \%)$. It is statistically significant that arm problems are observed more in veterinarians working with large animal types $(\mathrm{p}<0.05)$. The high level of job related stress and low job satisfaction statistically significantly affect the formation of WMSDs $(p<0.05)$. The study showed that a large number of veterinarians experienced work-related musculoskeletal pain and discomforts that could be caused by some physical and psychosocial risk factors. Therefore, it is recommended for veterinarians to receive education on ergonomics and exercise from the beginning of their professional lives to prevent WMSDs.
\end{abstract}

KEY WORDS: ergonomics; job related stress; lower back; neck; prevalence

Approximately $30 \%$ of all musculoskeletal discomforts detected in the world occur due to work-related reasons (1). Work-related musculoskeletal discomforts (WMSDs) account for approximately $34 \%$ of work day losses caused by all occupational diseases and occupational accidents, and the cost of compensation caused by these is almost 15-20 billion dollars annually (1).

WMSDs are commonly observed in the neck, upper extremities, and back regions (2). Physical and psychosocial risk factors such as repeated movements, excessive use of power, lifting heavy things, working in a bad and/or fixed posture, vibration, sitting or standing for a long time, job stress, job dissatisfaction, monotonous work, insufficient break times, and working with time constraints affect the formation of WMSDs (1, 3-5).

Studies conducted in many countries have revealed that musculoskeletal discomforts are an important problem among healthcare professionals (6). Work-related injuries occur more frequently in veterinarians when compared to other healthcare professionals (7). It is stated that WMSDs occur at rates as high as $49-96 \%$ in veterinarians $(7,8)$ and the problems are experienced mostly in the neck, shoulder, and low back regions (9). Veterinary medicine is a

Correspondence to: Mesut Ergan, Faculty of Health Sciences, Department of Physiotherapy and Rehabilitation, Süleyman Demirel Üniversity, East Campus, Çünür- Isparta/ Turkey. E-mail: mesutergan@sdu.edu.tr profession requiring strength and entailing a high risk of injury (10-12). Some physical and psychological risk factors such as a static or bad posture, repetitive work or work requiring excessive strength, standing for a long time during surgical operations, rectal palpation, obstetric procedures, lifting animals, driving, using computer, time pressure, job stress, career status, overtime work are connected to musculoskeletal discomforts observed in veterinarians ( 6 , $7,13,14)$.

Literature reports that $33 \%$ of veterinarians work in an abnormal posture and $15 \%$ of them work above the shoulder level for more than an hour a day (13). It is also observed that large animal veterinarians performing more than 250 rectal examinations a week have chronic arm, shoulder, and neck problems (15). Other studies have found that veterinarians experience pain due to repeated movements (for example during the injection procedure) $(16,17)$. Furthermore, work-related psychosocial factors like job dissatisfaction, stress, career status, time pressure, the attitude of the customer, the lack of knowledge of colleagues, the lack of understanding, and the lack of holidays are closely related to musculoskeletal problems in veterinarians $(6,8)$.

Taking into consideration that the effect of animal breeding on the economy of countries is considerable, the necessity of preventing workforce loss among veterinarians arises (9). Veterinarians in Turkey, and especially in the 
region where this research was performed, predominantly work with large animals. Therefore, they are considered to be under the greatest risk of WMSDs. While there are many studies conducted on WMSDs observed in healthcare professionals such as physicians, dentists, nurses, and physiotherapists in the literature, there is a limited number of studies conducted on veterinarians. On the other hand, in Turkey, there is no study conducted on musculoskeletal discomforts observed in veterinarians. The aim of this study was to determine the frequency of WMSDs observed in veterinarians and the risk factors of these problems in our country.

\section{METHODS}

This study is a cross-sectional study. The population of the study consisted of 758 veterinarians working in three provinces in southwest Turkey. The sample of the study included 207 veterinarians, chosen by a stratified sampling method, who agreed to participate to study. The veterinarians with musculoskeletal history (rheumatic disorder, trauma, surgery etc.) were excluded. The percentage response for this study was $60 \%$. A questionnaire was applied using the face-to-face interview method. The participants' demographic and occupational information were recorded and these included gender, age, bodyweight, height, body mass index (BMI: Body Mass Index was calculated as weight in kilograms divided by height in meters squared according to the subjects' self-reported weight and height data), work experience, number of working days per week, number of breaks of 15 minutes and more per day, position at work, type of animals they work with (9). The list of the types of animals veterinarians worked was obtained from literature: large animals, small animals, and mixed animals (large animals: cattle, pigs, horses, goats, and sheep; small animals: dogs, cats, domestic rodents, birds and reptiles) (10). The list was then showed to the veterinarians and they were asked to choose from the list. The perceived work stress and job satisfaction levels experienced by veterinarians were measured with a five-point Likert-type scale ranging as none, low, middle, high, and very high (6). The modified Nordic Musculoskeletal Questionnaire (NMQ) was used to evaluate the participants' WMSDs. Ten specific symptom regions of the body marked by mapping (neck, shoulders, arms, elbows, hands-wrists, back, low back, hips-thighs, knees, and feet-ankles) were examined. In the first section, questions were asked as to whether there were any problems (pain, discomfort, paresthesia, etc.) in the body parts indicated in the last 12 months. The second section provided questions on veterinarians' difficulty to perform normal work activities due to the aforementioned problem in the last 12 months and finally, in the third section, they were asked if they had to take time off from their work due to the mentioned problem in the last 12 months (18) The problem onset time scale allowing the veterinarians with
WMSDs to select one of the five different time periods (before the student period, during the student period, within four years after graduation, within 15 years after graduation, more than 15 years after graduation) was used to determine when these problems first appeared (19). The veterinarians were asked to select three out of seventeen work activities (obstetric procedures, vaccination, driving, rectal palpation, surgical procedures, handling/lifting, office activities/use of computer, animal examination, foot trimming, animal positioning, ultrasound, autopsies, blood collection/ intravenous injections, endoscopy, test for tuberculosis, dental examination, and radiography) specific to veterinary medicine to determine the work activities in which they experienced difficulties (8-10). The survey was developed and the pilot trialed on ten veterinarians. All ten veterinarians who took part in the pilot survey completed the questionnaires. After the essential revisions were made in the questionnaire, research was started.

\section{Statistical analysis}

Statistical analyses of all the data obtained from the participants were conducted with IBM SPSS Statistics version 20.0 programme. The demographic and occupational information on the participants, NMQ, onset time of WMSD and the results of the risk factors were described by percentage and rate. The chi-square test was conducted to compare the veterinarians' body parts with WMSDs in terms of the type of animals they worked with. First the chi-square test, and then the logistic regression analysis were conducted to examine the effect of the job stress level and satisfaction of veterinarians on the formation of WMSDs. The statistical significance level was accepted as $\mathrm{p}<0.05$.

\section{Ethics approval}

The ethics committee approval of the study was obtained from the Clinical Research Ethics Committee, Faculty of Medicine, Süleyman Demirel University, with the report No. 2149 dated 07.06.2013.

\section{RESULTS}

A total of 207 veterinarians, $91.3 \%$ males and $8.7 \%$ females, participated in the study. The demographic and occupational characteristics of the participants are presented in Table 1. The average age of the veterinarians who participated in the study was $35.36 \pm 7.57$ years, the average BMI was $27.41 \pm 3.87 \mathrm{~kg} \mathrm{~m}^{2}$ the average time spent in veterinary medicine field was $11.65 \pm 7.92$ years and the average of their working time was $59.42 \pm 20.22$ hours per week.

According to the results of NMQ, $49.8 \%$ of the veterinarians had discomforts mostly in the low back, $41.1 \%$ in the back and $39.1 \%$ in the neck regions. According to the results of the same questionnaire, the veterinarians had difficulty in performing their jobs and had 
Table 1 Distribution of demographic and occupational characteristics of veterinarians

\begin{tabular}{|c|c|c|c|}
\hline & & $\mathbf{N}$ & $\%$ \\
\hline \multirow{2}{*}{ Gender } & Male & 189 & 91.3 \\
\hline & Female & 18 & 8.7 \\
\hline \multirow{5}{*}{ Age } & $20-29$ years & 54 & 26.1 \\
\hline & $30-39$ years & 96 & 46.4 \\
\hline & $40-49$ years & 49 & 23.6 \\
\hline & $50-59$ years & 7 & 3.4 \\
\hline & $>60$ years & 1 & 0.5 \\
\hline \multirow{4}{*}{ BMI } & $18-24.99 \mathrm{~kg} \mathrm{~m}^{-2}$ & 60 & 29.0 \\
\hline & $25-29.99 \mathrm{~kg} \mathrm{~m}^{-2}$ & 102 & 49.3 \\
\hline & $30-34.99 \mathrm{~kg} \mathrm{~m}^{-2}$ & 39 & 18.8 \\
\hline & $>35 \mathrm{~kg} \mathrm{~m}^{-2}$ & 6 & 2.9 \\
\hline \multirow{4}{*}{$\begin{array}{l}\text { Job } \\
\text { experience }\end{array}$} & $1-9$ years & 92 & 44.4 \\
\hline & $10-19$ years & 76 & 35.8 \\
\hline & $20-29$ years & 36 & 17.4 \\
\hline & $>30$ years & 5 & 2.4 \\
\hline \multirow{3}{*}{$\begin{array}{l}\text { Working } \\
\text { days / week }\end{array}$} & 5 days & 76 & 36.7 \\
\hline & 6 days & 38 & 18.4 \\
\hline & 7 days & 93 & 44.9 \\
\hline \multirow{4}{*}{$\begin{array}{l}\text { Work breaks } \\
\text { per day }\end{array}$} & 0 & 2 & 1.0 \\
\hline & $1-4$ & 89 & 42.9 \\
\hline & $5-8$ & 31 & 14.9 \\
\hline & $9-12$ & 9 & 4.4 \\
\hline \multirow{3}{*}{$\begin{array}{l}\text { Work } \\
\text { position }\end{array}$} & Private practitioners & 102 & 49.3 \\
\hline & Public employees & 92 & 44.5 \\
\hline & University & 13 & 6.2 \\
\hline \multirow{3}{*}{ Practice type } & Small & 9 & 4.3 \\
\hline & Large & 94 & 45.5 \\
\hline & Mixed & 104 & 50.2 \\
\hline \multirow{3}{*}{$\begin{array}{l}\text { Work Stress } \\
\text { Level }\end{array}$} & No or low & 33 & 15.9 \\
\hline & Middle & 77 & 37.2 \\
\hline & High-very high & 97 & 46.9 \\
\hline \multirow{3}{*}{$\begin{array}{l}\text { Job } \\
\text { Satisfaction }\end{array}$} & High-very high & 92 & 44.5 \\
\hline & Middle & 88 & 42.5 \\
\hline & No or low & 27 & 13.0 \\
\hline
\end{tabular}

$N$-The number of participants, \% Percent

to take time off their work mostly due to the low back problems (Table 2).

When the distribution of the veterinarians' body parts with WMSD is considered in terms of the type of animals they work with, there is a statistically significant difference in arm problems $(\mathrm{p}<0.05)$. This significance results from those veterinarians who work with large animals (Table 3 ).

When the onset time of WMSDs is considered in terms of the body parts of veterinarians, it is observed that handwrist, low back, hip, and thigh problems occur in the first four years after graduation; neck, shoulder, arm, back, knee,

foot-ankle problems appear 5-15 years after graduation; elbow problems occur 15 years after graduation (Table 4).

Three occupational activities which veterinarians think are mostly responsible for WMSDs are obstetric procedures with $28 \%$, vaccination with $25.6 \%$ and driving with $23.2 \%$, respectively. Rectal palpation $18.8 \%$, surgical procedures $18.4 \%$, handling/lifting $15 \%$, office activities/ use of computer $14.5 \%$, animal examination $14 \%$, foot trimming $10.6 \%$, animal positioning $2.4 \%$, ultrasound $1.9 \%$, autopsies $1.9 \%$, blood collection/intravenous injections $1.4 \%$, endoscopy $0.5 \%$, test of tuberculosis $0.5 \%$ are other occupational risk factors determined by the veterinarians and none of the veterinarians defined dental examination and radiography as an occupational risk factor.

When the effect of psychosocial risk factors on those with (Group 1) and without (Group 2) WMSDs is considered, the high level of job stress and low job satisfaction statistically significantly affect the formation of WMSDs (Table 5). The high level of job stress (OR:2.531, $95 \%$ C.I.:1.057-6.063, p<0.05) and the no-lowmiddle level of job satisfaction (OR:2.722, 95 \% C.I.:1.193$6.210, \mathrm{p}<0.05)$ in the analysis of psychosocial risk factors conducted with logistic regression are the risk factors for WMSDs in veterinarians (Table 6). The frequency of WMSDs increases 2.53 times when the level of job stress is high and 2.72 times with the no-low-middle level of job satisfaction.

\section{DISCUSSION}

This study was intended to determine the frequency of WMSDs occurring in various body parts of veterinarians, as well as the onset time, and work-related and psychosocial risk factors of these discomforts.

Table 2 Nordic Musculoskeletal Questionnaire (NMQ) results

\begin{tabular}{lcccccc}
\hline \multirow{2}{*}{$\begin{array}{l}\text { Part of } \\
\text { body }\end{array}$} & \multicolumn{2}{c}{$\begin{array}{c}\text { Experience } \\
\text { of Pain }\end{array}$} & \multicolumn{2}{c}{$\begin{array}{l}\text { Difficulty at } \\
\text { Work }\end{array}$} & \multicolumn{3}{c}{$\begin{array}{c}\text { Absent } \\
\text { from Work }\end{array}$} \\
\cline { 2 - 7 } & $\mathbf{N}$ & $\mathbf{\%}$ & $\mathbf{N}$ & $\mathbf{\%}$ & $\mathbf{N}$ & $\mathbf{\%}$ \\
\hline Neck & 81 & 39.1 & 39 & 18.8 & 13 & 6.3 \\
\hline Shoulders & 77 & 37.2 & 35 & 16.9 & 5 & 2.4 \\
\hline Arms & 60 & 29.0 & 25 & 12.1 & 4 & 1.9 \\
\hline Elbows & 24 & 11.6 & 12 & 5.8 & 3 & 1.4 \\
\hline $\begin{array}{l}\text { Wrists / } \\
\text { Hands }\end{array}$ & 58 & 28.0 & 24 & 11.6 & 5 & 2.4 \\
\hline Back & 85 & 41.1 & 34 & 16.4 & 5 & 2.4 \\
\hline Low back & 103 & $\mathbf{4 9 . 8}$ & 53 & $\mathbf{2 5 . 6}$ & 25 & $\mathbf{1 2 . 1}$ \\
\hline $\begin{array}{l}\text { Hips/ } \\
\text { Thighs }\end{array}$ & 27 & 13.0 & 11 & 5.3 & 7 & 3.4 \\
\hline Knees & 62 & 30.0 & 23 & 11.1 & 4 & 1.9 \\
\hline $\begin{array}{l}\text { Ankles / } \\
\text { Feet }\end{array}$ & 50 & 24.2 & 20 & 9.7 & 5 & 2.4 \\
\hline $\begin{array}{l}\text { N - Number of participants with work-related } \\
\text { discomforts; \% Percent }\end{array}$ & \multicolumn{5}{l}{ musculoskeletal } \\
\hline
\end{tabular}


Table 3 Distribution of veterinarians with Work-related musculoskeletal discomforts (WMSDs) according to practice type

\begin{tabular}{|c|c|c|c|c|c|c|c|c|c|}
\hline \multirow{2}{*}{ Part of body } & \multicolumn{2}{|c|}{ Small animal } & \multicolumn{2}{|c|}{ Large animal } & \multicolumn{2}{|c|}{ Mixed animal } & \multicolumn{2}{|c|}{ Total } & \multirow{2}{*}{$\mathbf{P}^{*}$} \\
\hline & $\mathbf{N}$ & $\%$ & $\mathbf{N}$ & $\%$ & $\mathbf{N}$ & $\%$ & $\mathbf{N}$ & $\%$ & \\
\hline Neck & 5 & 55.6 & 33 & 35.1 & 43 & 41.3 & 81 & 39.1 & 0.392 \\
\hline Shoulders & 3 & 33.3 & 33 & 35.1 & 41 & 39.4 & 77 & 37.2 & 0.797 \\
\hline Arms & 2 & 22.2 & 36 & 38.3 & 22 & 21.2 & 60 & 29.0 & 0.027 \\
\hline Elbows & 0 & 0.0 & 14 & 14.9 & 10 & 9.6 & 24 & 11.6 & 0.276 \\
\hline Wrists / Hands & 2 & 22.2 & 29 & 30.9 & 27 & 26.0 & 58 & 28.0 & 0.690 \\
\hline Back & 4 & 44.4 & 34 & 36.2 & 47 & 45.2 & 85 & 41.1 & 0.426 \\
\hline Low back & 5 & 55.6 & 49 & 52.1 & 49 & 47.1 & 103 & 49.8 & 0.732 \\
\hline Hips/Thighs & 2 & 22.2 & 7 & 7.4 & 18 & 17.3 & 27 & 13.0 & 0.085 \\
\hline Knees & 3 & 33.3 & 23 & 24.5 & 36 & 34.6 & 62 & 30.0 & 0.290 \\
\hline Ankles / Feet & 3 & 33.3 & 19 & 20.2 & 28 & 26.9 & 50 & 24.2 & 0.439 \\
\hline
\end{tabular}

N-Number of participants with work-related musculoskeletal discomforts; \% Percent; *Chi-square test

As a result of the study, it was identified that the body parts causing veterinarians most problems were low back with $49.8 \%$, back with $41.1 \%$, and neck with $39.1 \%$. While the body parts causing most difficulties in veterinarian work activities due to feeling pain and discomfort are low back with $25.6 \%$ and neck with $18.8 \%$, the body parts which make people take time off from work due to feeling pain and discomfort are low back with $12.1 \%$ and neck with $6.3 \%$.

Scuffham et al. (8) stated that the frequency of WMSDs in veterinarians in terms of body parts was $73 \%$ for the low back region, $59 \%$ for shoulders, and $58 \%$ for the neck region. Moreover, they stated that $42 \%$ of those with low back problems, $28 \%$ of those with shoulder and hand-wrist problems, and $25 \%$ of those with neck problems experienced difficulties in work activities; $9 \%$ of those with low back problems, $4 \%$ of those with hand-wrist problems, and $3 \%$ of those with neck, shoulder, and knee problems had to take time off from their work due to the discomfort they experienced. In another similar study conducted by
Smith et al. (6), the frequency of work-related low back and neck problems in veterinarians was found to be at high rates such as $62.6 \%$ and $56.9 \%$, respectively. It was reported that the rates of problems that affected work in this study were $31.8 \%$ for the low back region, $22 \%$ for the neck region, and the rates of staying away from work were $6.1 \%$ for the low back region and $2.8 \%$ for the neck region.

O'Sullivan et al. (20) stated that the frequency of experiencing pain in terms of body parts was $35 \%$ for low back, $25 \%$ for neck, and $20 \%$ for shoulders, and $34 \%$ of veterinarians stayed away from work. In a study conducted on cardiologist veterinarians, the most frequent painful regions were neck with $54 \%$, shoulders with $52 \%$, handswrists with $42 \%$, and low back with $35 \%$, and, moreover, the working performance of $36 \%$ of all participants decreased, $12 \%$ of them had to take time off from work (21).

In our study, the rates of being affected in body parts are similar to most studies. However, in a study about

Table 4 Distribution of work-related musculoskeletal discomforts (WMSDs) first occurrence times

\begin{tabular}{|c|c|c|c|c|c|c|c|c|c|c|}
\hline \multirow[t]{2}{*}{ Part of body } & \multicolumn{2}{|c|}{$\begin{array}{c}\text { Before the } \\
\text { student period }\end{array}$} & \multicolumn{2}{|c|}{$\begin{array}{l}\text { During the } \\
\text { student period }\end{array}$} & \multicolumn{2}{|c|}{$\begin{array}{l}\text { Within } 4 \text { years } \\
\text { after graduation }\end{array}$} & \multicolumn{2}{|c|}{$\begin{array}{l}\text { Within 5-15 } \\
\text { years after } \\
\text { graduation }\end{array}$} & \multicolumn{2}{|c|}{$\begin{array}{c}\text { More than } 15 \\
\text { years after } \\
\text { graduation }\end{array}$} \\
\hline & $\mathbf{N}$ & $\%$ & $\mathbf{N}$ & $\%$ & $\mathbf{N}$ & $\%$ & $\mathbf{N}$ & $\%$ & $\mathbf{N}$ & $\%$ \\
\hline Neck & 5 & 6.2 & 11 & 13.6 & 26 & 32.1 & 32 & 39.5 & 7 & 8.6 \\
\hline Shoulders & 5 & 6.4 & 11 & 14.1 & 21 & 26.9 & 32 & 41.0 & 9 & 11.5 \\
\hline Arms & 1 & 1.7 & 8 & 13.6 & 16 & 27.1 & 21 & 35.6 & 13 & 22.0 \\
\hline Elbows & 0 & 0 & 1 & 4.2 & 8 & 33.3 & 5 & 20.8 & 10 & 41.7 \\
\hline Wrists / Hands & 2 & 3.4 & 4 & 6.9 & 23 & 39.7 & 20 & 34.5 & 9 & 15.5 \\
\hline Back & 2 & 2.3 & 13 & 15.1 & 31 & 36.0 & 32 & 37.2 & 8 & 9.3 \\
\hline Low back & 2 & 1.9 & 14 & 13.6 & 40 & 38.8 & 34 & 33.0 & 13 & 12.6 \\
\hline Hips/Thighs & 5 & 18.5 & 2 & 7.4 & 9 & 33.3 & 8 & 29.6 & 3 & 11.1 \\
\hline Knees & 3 & 4.8 & 6 & 9.7 & 19 & 30.6 & 21 & 33.9 & 13 & 21.0 \\
\hline Ankles / Feet & 0 & 0 & 5 & 10.0 & 11 & 22.0 & 23 & 46.0 & 11 & 22.0 \\
\hline
\end{tabular}

$N$ - Number of participants with work-related musculoskeletal discomforts; \% Percent 
Table 5 Distribution of psychosocial risk factors levels of Group 1 and Group 2

\begin{tabular}{|c|c|c|c|c|c|c|}
\hline \multirow{2}{*}{$\begin{array}{l}\text { Psychosocial Risk } \\
\text { Factors }\end{array}$} & & \multicolumn{2}{|c|}{$\begin{array}{l}\text { With WMSDs } \\
\text { (Group 1) }\end{array}$} & \multicolumn{2}{|c|}{$\begin{array}{l}\text { Without WMSDs } \\
\text { (Group 2) }\end{array}$} & \multirow[t]{2}{*}{$\mathbf{P}$} \\
\hline & & $\mathbf{N}$ & $\%$ & $\mathbf{N}$ & $\%$ & \\
\hline \multirow{3}{*}{ Work Stress Level } & No or low & 23 & 69.7 & 10 & 30.3 & \multirow{3}{*}{$0.002 *$} \\
\hline & Middle & 64 & 83.1 & 13 & 16.9 & \\
\hline & High & 89 & 91.8 & 8 & 8.2 & \\
\hline \multirow{3}{*}{ Job Satisfaction } & High & 71 & 77.2 & 21 & 22.8 & \multirow{4}{*}{0.011} \\
\hline & Middle & 82 & 93.2 & 6 & 6.8 & \\
\hline & No or low & 23 & 85.2 & 4 & 14.8 & \\
\hline Total & & 176 & 85.0 & 31 & 15.0 & \\
\hline
\end{tabular}

$N$ - Number of participants; \% Percent; *Chi-square for trend; WMSDs - Work-related musculoskeletal discomforts; Group 1 - With WMSDs; Group 2 - Without WMSDs

cardiologist veterinarians, the most affected part was the neck because of the intensive use of ultrasound. But in our study the veterinarians were not cardiologists, they were general practitioners. So the most affected part was low back. The rates of having difficulties during work and taking time off from work were found to be higher when compared to most studies. The reasons for the fact that the rates of being affected in body parts were different may be related to the fact that the veterinarians in our study were young and their exposure duration to the risk factors was brief. And the reasons for the high rates of having difficulties during work and taking time off from work may be related to the fact that necessary precautions were not taken in the population experiencing pain. In addition, veterinarians working in public institutions could take time off from work more easily when compared to veterinarians working at clinics. Moreover, the reason of the high rates of back and low back problems experienced in our study may be due to the need of more driving (13).

The type of animals with which veterinarians work is related to the frequency and severity of WMSDs and the studies conducted support this opinion (14). When the distribution of veterinarians' body parts with WMSD was examined in our study in terms of the type of animal they worked with, it was found out that arm problems were statistically significant and were observed more in veterinarians working with large animals. In a study conducted in veterinarians in California, those working with large animals experienced upper extremity and knee problems more than those working with small and mixed type animals (10). Kozak et al. (14) stated that veterinarians working with large and mixed type of animals reported upper body problems more frequently. In another study, veterinarians working with horses experienced upper body problems more (12). It was observed that more than $95 \%$ of the veterinarians evaluated in this study worked with mixed or large animals. Since there are a limited number of veterinarians working with small animals, comparison with other studies in this group would not be worthwhile. However, when veterinarians working with mixed and large animals are compared, similar results with literature are obtained. When the studies found in literature were examined closely, the problems of body parts and the comparisons between the types of animals veterinarians worked with were not mentioned in detail. The fact that veterinarians perform rectal palpation examination frequently can impact the frequency of arm problems in those working with large animals.

In our study, the period of time during which WMSDs appeared most frequently and the effect of work experience on this were examined for the parts of the body. In conclusion, it was determined that hand-wrist, low back, hip, and thigh problems occurred in the first four years after graduation; neck, shoulder, arm, back, knee, foot-ankle problems occurred 5-15 years after graduation; elbow problems mostly occurred 15 years after graduation. When the literature was examined, it was observed that only a general evaluation was made on the results and veterinarians did not evaluate the parts of the body separately. While some studies indicate that an increase in professional experience reduces the frequency and symptoms of WMSDs and that these result from the inexperience of newly graduated individuals $(7,22)$, some studies support the opposite of this situation. Randall et al. (23) indicated that every five-year increase in work experience of the veterinarians performing ultrasound examination increases WMSDs symptoms. Kozak et al. (14) stated that elderly veterinarians experienced WMSDs more when compared to young veterinarians and related this situation to the fact that physical and muscular capacity decreased progressively with age $(14,24)$. Büker et al. (25) said in their study conducted on physicians that WDSMs occurred 7.2 years on average after taking on a job. When the results of this study are examined, it is observed that the frequency of neck, shoulder, arm, elbow, back, knee, and foot-ankle problems increases together with experience. It is believed that this situation occurs due to the fact that people do not follow ergonomic recommendations on their workplaces although the negative effects of bad posture and inappropriate positions accumulate and increase with their professional experience. 
The risk factors in veterinary medicine are similar to the general occupational risk factors and include physical and psychosocial risk factors (9). Physical risk factors mostly originate from occupational practices frequently performed by veterinarians. Rectal palpation, obstetric procedures, standing for a long time during surgery can be given as some examples of occupational practices. Driving and computer use are considered among the possible reasons for the occurrence of these factors $(9,10)$. In the study we conducted, the three most risky occupational activities indicated by veterinarians were obstetric procedures with $28 \%$, vaccination with $25.6 \%$, and driving with $23.2 \%$. According to Berry et al. (10), those who work with small and mixed animal types mostly complain of discomforts due to lifting. In addition, those working with small animals have problems at the rate of $28 \%$ when carrying required equipment for work and at the rate of $12 \%$ when standing for a long time during surgery. Those working with large animals have problems in terms of birth manipulations, rectal palpation, and horse dental care. Loomans et al. (12) indicated repetitive movements such as rectal palpation, ultrasound, radiography, dental and foot care, and abnormal posture as risk factors. Randall et al. (23) also indicated repetitive movements and ultrasound including abnormal posture as risk factors. Scuffham et al. $(8,26)$ indicated work activities such as lifting, rectal palpation, carrying animals, and surgery as risk factors. Kozak et al. (14) indicated odontotherapy, obstetric procedures, radiological evaluation, and rectal palpation as risk factors. Hafer et al. (17) stated that $51 \%$ of veterinarians were exposed to repeated movements during the injection procedure and this situation caused pain.

The vaccination procedures of animals in our country are controlled by veterinarians working as public employees. The fact that same individuals perform these activities all the time triggers the emergence of WMSDs. This situation may be the reason for the fact why 'vaccination' stands out in our study.

There are a limited number of studies conducted on psychosocial risk factors in veterinarians. In these studies, it was stated that an increase in job stress increases the frequency and severity of WMSDs (14). The effect of psychosocial risk factors was examined in our study and the high level of job stress and low job satisfaction statistically significantly affected WMSDs and increased their rate of incidence. The rate of the incidence of WMSDs increases 2.53 times with the high level of job stress and 2.72 times with the no-low-middle level of job satisfaction. Scuffham et al. stated that job difficulty and dissatisfaction increased the rate of incidence of WMSDs 2.72 times (8). White said that stress increased muscle tension and led to the formation or increase of WMSD, and this made it a vicious cycle by making the person more stressful and dissatisfied (27). In a study conducted in Australia, it was stated that work-related stress sources such as long working hours per day, insufficient holidays and the lack of rest breaks were effective in the emergence of WMSDs (28). Also in other studies, it was emphasized that work-related stress and dissatisfaction increased the severity of workrelated musculoskeletal discomforts $(12,14)$. We consider that the reasons for work-related stress and dissatisfaction may be a busy schedule, inadequate resting, heavy working conditions ( $44.9 \%$ of the veterinarians in this region must work seven days a week because animal owners want health care all the time) and economic concerns.

This study has some limitations. The age of the veterinarians in this study was young. It may not be possible to generalise the results since this study was conducted in three provinces. Therefore, there is a need for studies with wider participation in different geographical regions. Another limitation is the fact that since the number of veterinarians working with small animals among the participants of the study was very low, determinative comparisons in terms of the type of animals could not be performed. Furthermore, the participants were mostly evaluated subjectively, however, it is recommended to use objective evaluation methods in future studies. An additional limitation of this study was the insufficiency in indicating the cause and effect relation because of its crosssectional nature. The knowledge about the presence of discomfort and its relation with working activities depended on the subjects' self-reports. Therefore, there was no way of finding out the effects of non-work activities such as sporting activities and housework on musculoskeletal discomforts.

In Turkey, very little data exists on the prevalence and incidence of WMSDs in different occupations. Moreover, the current study is the first to report about WMSDs in Turkish veterinarians. The current study indicated that a large majority of veterinarians experienced work-related musculoskeletal pain and discomforts, and some physical and psychosocial risk factors which can cause such problems were described. In the light of these data, it is important to prevent WMSDs in veterinarians. Within the context of the prevention strategy, it is recommended to provide ergonomics training to veterinarians during and after undergraduate education to make them use their body and the occupational equipment more effectively, and to increase their levels of knowledge and awareness about the

Table 6 Logistic regression model of psychosocial risk factors that lead to Work-related musculoskeletal discomforts (WMSDs)

\begin{tabular}{llcc}
\hline $\begin{array}{l}\text { Psychosocial risk } \\
\text { factors }\end{array}$ & p & OR & $\begin{array}{c}\% 95 \text { Confidence } \\
\text { Interval } \\
\text { Min-Max }\end{array}$ \\
\hline
\end{tabular}

Work Stress Level

(Reference: No-

low-middle)

\begin{tabular}{llll} 
High & $\mathbf{0 . 0 3 7}$ & 2.531 & $1.057-6.063$ \\
\hline
\end{tabular}

Job Satisfaction

(Reference: High)

$\begin{array}{llll}\text { No-low-middle } & \mathbf{0 . 0 1 7} & 2.722 & 1.193-6.210\end{array}$


identification of the early signs of these problems and taking precautions immediately. The efforts as to the design of the work aimed at addressing pain and discomfort prevention in veterinarians may include the use of specialised equipment, such as adjustable height surgery tables, use of correct manual-handling techniques and appropriate use of safety precautions, use of suitable posture (for example during the ultrasound procedure) and body mechanics, use of proper rest/work ratios (especially for rectal palpation), regular rotation of tasks/ jobs, and organisational strategies such as the regulation of workload and work environment. In addition to these, it may also be necessary to develop the protective exercise habit aimed to decrease the overload of the musculoskeletal system and the risk of the development of degenerative changes by providing training to veterinarians on the exercises that can increase muscle strength, endurance, and coordination, and the elasticity of tendon and ligaments.

\section{Acknowledgement}

The authors received financial support from Scientific Research Projects Coordination Unit of Süleyman Demirel University for the research and/or authorship of this article.

\section{REFERENCES}

1. Çalışma ve Sosyal Güvenlik Bakanlığı, İş Sağlığ 1 ve Güvenliği Genel Müdürlüğü (İSGGM). Mesleki Kas İskelet Sistemi Hastal1kları [Ministry of Labour and Social Security of the Republic of Turkey, Directorate General of Occupational Health and Safety. Occupational Musculoskeletal Diseases, in Turkish]. ISG Dergisi 2007;34:6-16.

2. European Agency for Safety and Health at Work (EU-OSHA) European Risk Observatory Report [displayed 19 December 2016]. Available at https://osha.europa.eu/en/tools-andpublications/publications/reports/TERO09009ENC

3. Akbal A, Eroğlu P, Yılmaz H, Tutkun E. Mesleki Maruziyetler ve Kas İskelet Sistemi Bulgular1 [Occupational exposures and musculoskeletal system findings, in Turkish]. J PMR Sci 2012;15:73-6.

4. Özcan E. İş Yerinde Ergonomik Risklerin Değerlendirilmesi ve Hızlı Maruziyet Değerlendirme (HMD) Yöntemi [Ergonomics risk assessment and Quick Exposure Check (QEC), in Turkish]. Mühendis ve Makina 2011;52:86-9.

5. Esen H, Fığlalı N. Çalışma Duruşu Analiz Yöntemleri ve Çalışma Duruşunun Kas-İskelet Sistemi Rahatsızlıklarına Etkileri [Working posture analysis methods and the effects of working posture on musculoskeletal disorders, in Turkish]. SAU J Sci 2013; 17:41-51.

6. Smith DR, Leggat PA, Speare R. Musculoskeletal disorders and psychosocial risk factors among veterinarians in Queensland Australia. Aust Vet J 2009;87:260-5. doi: 10.1111/j.1751-0813.2009.00435.x

7. Fritschi L, Day L, Shirangi A, Robertson I, Lucas M, Vizard A. Injury in Australian veterinarians. Occup Med 2006;56:199-203. doi: 10.1093/occmed/kqj037

8. Scuffham AM, Legg SJ, Firth EC, Stevenson MA. Prevalence and risk factors associated with musculoskeletal discomfort in New Zealand veterinarians. Appl Ergon 2010;41:444-53. doi: 10.1016/j.apergo.2009.09.009

9. Scuffham AM. Musculosceletal Discomfort in Veterinarians [dissertation]. Palmerston North: Massey University; 2009.

10. Berry SL, Susitaival P, Ahmadi A, Schenker MB. Cumulative trauma disorders among California veterinarians. Am J Ind Med 2012;55:855-61. doi: 10.1002/ajim.22076

11. Lucas M, Day L, Fritschi L. Serious injuries to Australian veterinarians working with cattle. Aust Vet J 2013;91:57-60. doi: 10.1111/j.1751-0813.2012.01014.x

12. Loomans JBA, van Weeren-Bitterling MS, van Weeren PR, Barneveld A. Occupational disability and job satisfaction in the equine veterinary profession: How sustainable is this "tough job" in a changing world? Equine Vet Educ 2008;20:597-607. doi: 10.2746/095777308X360177

13. Reijula K, Räsänen K, Hämäläinen $M$, Juntunen K, Lindbohm ML, Taskinen H, Bergbom B, Rinta-Jouppi M. Work environment and occupational health of Finnish veterinarians. Am J Ind Med 2003;44:46-57. doi: 10.1002/ ajim. 10228

14. Kozak A, Schedlbauer G, Peters C, Nienhaus A. Self-reported musculoskeletal disorders of the distal upper extremities and the neck in German veterinarians: A cross-sectional study. PLoS One 2014;9(2). doi: 10.1371/journal.pone.0089362

15. Ailsby RL. Occupational arm, shoulder and neck syndrome affecting large animal practitioners. Can Vet J 1996;37:411. PMCID: PMC1576455

16. Hill DJ, Langley RL, Morrow WM. Occupational injuries and illnesses reported by zoo veterinarians in the United States. J Zoo Wildl Med 1998;29:371-85. PMID: 10065844

17. HaferAL, Langley RL, Morrow WEM, Tulis JJ. Occupational hazards reported by swine veterinarians in the United States. J Swine Health Prod 1996;4:128-41.

18. Kuorinka I, Jonsson B, Kilbom A, Vinterberg H, BieringSørensen F, Andersson G, Jørgensen K. Standardised Nordic questionnaires for the analysis of musculoskeletal symptoms. Appl Ergon 1987;18:233-7. doi: 10.1016/00036870(87)90010-X

19. Cromie JE, Robertson VJ, Best MO. Work-related musculoskeletal disorders in physical therapists: Prevalence, severity, risks, and responses. Phys Ther 2000;80:336-51. doi: $10.1093 / \mathrm{ptj} / 80.4 .336$

20. O'Sullivan K, Curran N. It shouldn't happen to a vet... Occupational injuries in veterinary practitioners working in Ireland. Irish Vet J 2008;61:584-6.

21. MacDonald K, King D. Work-related musculoskeletal disorders in veterinary echocardiographers: A cross-sectional study on prevalence and risk factors. J Vet Cardiol 2014;16:27-37. doi: 10.1016/j.jvc.2014.01.001

22. Gabel CL, Gerberich SG. Risk factors for injury among veterinarians. Epidemiology 2002;13:80-6. PMID: 11805590

23. Randall E, Hansen C, Gilkey D, Patil A, Bachand A, Rosecrance J, Douphrate D. Evaluation of ergonomic risk factors among veterinary ultrasonographers. Vet Radiol U 1 trasound 2012;53:459-64. doi : 10.1111/j.1740-8261.2012.01942.x

24. de Zwart BC, Frings-Dresen MH, van Dijk FJ. Physical workload and the ageing worker: A review of the literatüre. Int Arch Occup Environ Health 1995;68:1-12. PMID: 8847107 
25. Büker N, Aslan E, Altuğ F, Cavlak U. An analysis study of musculoskeletal problems in medical doctors. DPU Fen Bilim Enst 2006;10:163-70.

26. Scuffham AM, Firth EC, Stevenson MA, Legg SJ. Tasks considered by veterinarians to cause them musculoskeletal discomfort, and suggested solutions. N Z Vet J 2010;58:3744. doi: 10.1080/00480169.2010.64872
27. White SC. Prevalence and risk factors associated with musculoskeletal discomfort in spay and neuter veterinarians. Animals 2013;3:85-108. doi: 10.3390/ani3010085

28. Smith DR, Leggat PA, Speare R, Townley-Jones M. Examining the dimensions and correlates of workplace stress among Australian veterinarians. J Occup Med Toxicol 2009;4:32. doi: 10.1186/1745-6673-4-32

\section{Ispitivanje mišićno-koštanih tegoba povezanih s radom i rizičnih čimbenika u veterinara}

Cilj ovog istraživanja bio je utvrditi učestalost mišićno-koštanih tegoba povezanih s radom (eng. work-related musculoskeletal discomforts - WMSD) koje su primijećene u veterinara te rizičnih čimbenika koji mogu dovesti do tih tegoba. U ispitivanje je bilo uključeno dvjesto sedam veterinara koji rade u trima provincijama u jugozapadnoj Turskoj. Prikupljeni su demografski i podaci o radnome mjestu sudionika. Primjenom Modificiranog nordijskog upitnika o mišićnokoštanim tegobama (The Modified Nordic Musculoskeletal Questionnaire) prikupljeni su podaci korišteni u procjeni mišićno-koštanih problema u različitim dijelovima tijela koji uzrokuju poteškoće na radu i rezultiraju odsutnošću s posla. Utvrđeno je kako 49,8 \% veterinara uglavnom ima problem s donjim dijelom leđa, 41,1\% ima problem s leđima, a 39,1\% $\mathrm{s}$ vratom. Učestalost WMSD-a povećava se s povećanjem radnog iskustva. Tri su radne aktivnosti tijekom kojih veterinari imaju zdravstvenih tegoba: opstetrički postupci (28 \%), vakcinacija $(25,6 \%)$ i vožnja $(23,2 \%)$. Statistički su značajni problemi s rukama od šake do ramena u veterinara koji rade s velikim životinjama $(\mathrm{p}<0,05)$. Visoka razina stresa povezanog s poslom i niska razina zadovoljstva radnim mjestom statistički značajno utječu na pojavu WMSD-a $(\mathrm{p}<0,05)$. Ispitivanje je pokazalo da velik broj veterinara osjeća mišićno-koštanu bol i tegobe koje su povezane s poslom, a koje bi mogle biti uzrokovane nekim fizikalnim ili psihosocijalnim rizičnim čimbenicima. Kako bi se spriječila pojava mišićno-koštanih tegoba povezanih s radom, veterinarima se preporučuje edukacija o ergonomiji i vježbanje od samog početka profesionalnog života. 